\title{
THE SELF-EFFICACY AND ANXIETY IN LEARNING MATHEMATICS OF COLLEGE STUDENTS
}

\author{
*Francis Jose D. Bearneza
}

\begin{tabular}{l}
\hline Paper Received: 25.02.2020 / Paper Accepted: 30.05.2020 / Paper Published: 03.06.2020 \\
Corresponding Author: Francis Jose D. Bearneza; Email: francisjosebearneza@ @mail.com;doi:10.46360/globus.xxxxxxx \\
\hline
\end{tabular}

\begin{abstract}
The study is aimed to determine the Level of Self-efficacy and Anxiety in Learning Mathematics of the First Year College Students of the Carlos Hilado Memorial State College for Second Semester Academic Year 2015-2016. The Descriptive-Correlational research design was employed, because this method is used to discover relationships among variables and to allow the prediction of future events from present knowledge (Stangor, 2015). Utilizing the Yamani's formula, the number of sample was 347 participants out of total population of 4375 First year College Students. Both of the students' level of Self-efficacy and Anxiety in Learning Mathematics when taken as whole was high, the level of self-efficacy of the participants when grouped according to campus, sex and father's educational attainment was high, however, when grouped according to field of specialization, the BSHRM illustrated a low self-efficacy level. Furthermore, there was a significant difference on the level of Selfefficacy when grouped according to sex. While on the level of Anxiety, the Talisay and Alijis campus; female participants; AB, BSIT, BEED, BSHRM, BSENTRP and BSCRIM; and participant's whose father with Elementary Graduate, High School Level and High School Graduate Educational Attainment has a high level of Anxiety in Learning Mathematics. Moreover, there was a significant difference on the level of anxiety when grouped according to father's educational attainment. The results also showed that there was a weak negative relationship between the level of Self-efficacy and Anxiety of students' in learning mathematics.
\end{abstract}

Keywords: Self-efficacy and Anxiety, Mathematics, Student.

\section{Introduction}

College mathematics achievement is frequently influenced by students' mathematics self-efficacy and mathematics anxiety. Accordingly, instructors endeavor is to build the students' mathematics selfefficacy, alleviate mathematics anxiety, or strengthen positive mathematics attitudes, but instructors lack the tools to consistently, realistically, and competently evaluate these constructs. Since college mathematics instructors respond to the need for the development of students' mathematics literacy, the essential role of students' mathematics self-efficacy has received increased attention (Hannula, 2006; Pape \& Smith, 2002).

The poor self-efficacy in mathematics of college students habitually decreases their enthusiasm to study and in the end can lead to low mathematics accomplishment. According to the study of Higbee and Thomas (1999) found that mathematics selfefficacy, along with other affective factors such as test anxiety and perceived usefulness of mathematics, influenced students' mathematical performances. The results of their study recommend to instructors that focusing on their teaching mathematical content is inadequate from several students to study mathematics. College mathematics instructors should also consider the emotional or attitudinal factors that influenced students in learn mathematics.

The mathematics self-efficacy was directly related; mathematics anxiety can also influence the students' performances in mathematics program. Mathematics anxiety is related to general anxiety as well as the assessment of anxiety, but it also extends to a further detailed apprehension of mathematics (Hembree, 1990; Kazelskis et al., 2000). As Richardson and Suinn (1972) point out: "Mathematics anxiety involves feelings of tension
and anxiety that interfere with the manipulation of
numbers and the solving of mathematical problems
in a wide variety of ordinary life and academic
situations".
Individually, the impact of mathematics anxiety
varies based on each student. The students who
suffer from higher levels of mathematics anxiety
typically develop negative attitudes and emotions
toward mathematics. According to Cates and
Rhymer (2003), the students with higher levels of 
mathematics anxiety had considerably lower computational fluency in all areas of mathematical computations; these students, in turn, had lower levels of achievement in mathematics.

The Mathematics Department of Carlos Hilado Memorial State College Talisay Campus has tried to developed strategies and practices to cater the level of learning of the students to learn mathematics without complexity. The researcher is very interested to establish the self-efficacy, and anxiety students in learning mathematics.

\section{Statement of the Problem}

The study was conducted to determine the level of self-efficacy and anxiety first year College students in learning mathematics. Specifically, this study aims to determine:

1. What is the level of self-efficacy and anxiety of the first year college students in learning mathematics?

2. What is the level of level of self-efficacy and anxiety of the first year college students in learning mathematics when taken as a whole and grouped according to:

a. Campus

b. Sex

b. Fathers Educational Attainment, and

c. Field of Specialization?

3 . Is there a significant difference in level of selfefficacy and anxiety of the first year college students in learning mathematics when grouped according to

a. Campus

b. Sex

b. Fathers Educational Attainment, and

c. Field of Specialization?

4. Is there a significant relationship between the level of self-efficacy and anxiety of the first year college students in learning mathematics?

\section{Hypotheses}

1. There is no significant difference in level of selfefficacy and anxiety of the first year college students in learning mathematics when grouped according to: a. Sex

b. Fathers Educational Attainment, and

c. Field of Specialization.

2. There is no significant relationship between level of self-efficacy and anxiety of the first year college students in learning mathematics.

\section{Theoretical Framework}

Numerous studies have been conducted on selfefficacy and anxiety of students in learning mathematics. The self-efficacy and anxiety pertained to in this study will be the first year students of Carlos Hilado Memorial State College.
This study was anchored on the Self-efficacy theory of Bandura (1997; Pajares, 2006), states that the key of contentions that regards the role of self-efficacy beliefs in an individual functioning is that "people's level of motivation, affective states, and actions are based more on what they believe than on what is objectively true". This reason, how people perform often better expected by the beliefs they hold about their capabilities than by what they are actually capable of accomplishing, for these self-efficacy perceptions help establish what individuals do with the knowledge and skills they have.

In addition, the higher the perceived efficacy, the higher the goal aspirations people may adopt and develop firmer commitment in order to achieve those goals. The educational activities ought to foster self-efficacy through the use of social interaction. By doing so, the learning environment is structured to de-emphasize competition and highlight self-comparison of progress to build a sense of self-efficacy and promote academic achievement." (Peer \& McClendon, 2002)

Furthermore, according to Pajares (2002), the most significant foundation is the interpreted result of one's prior performance, or mastery experience. An individual that engage in tasks and activities, interprets their results of their actions, use the interpretations to develop their capabilities to engage in subsequent tasks or activities, and act in with the beliefs created. Naturally, outcomes interpreted as successful raise self-efficacy; those interpreted as failures lower it. People who acquire low sense of efficacy frequently discount their successes rather than change their self-belief. After an individual achieve success through persistent effort, some continue to distrust their efficacy to increase a similar attempt. Therefore, mastering experiences are simply raw data, and many factors that manipulate information are cognitively processed and affect an individual's self-appraisal.

The Mathematics anxiety have been defined as thoughts of apprehension and anxiety that interfere with the manipulation of numbers and the solving of mathematical problems in a wide variety of ordinary life and academic situations Math anxiety can cause one to forget and lose one's self-confidence (Tobias, S. 1993, Phillips, M. 2015). Furthermore, pressure of timed tests and risk of public embarrassment have long been recognized as sources of unproductive tension among many students. Moreover, the traditional mathematics classroom cause great anxiety in many students that are imposed authority, public exposure and time deadlines.

According to Taylor, S. (2010), people can experience anxiety sensations for several reasons; some people fear them because they misunderstand 
them as harbingers of imminent physical or mental disaster, others may fear them because of social evaluation concerns that are not directly linked to genuine catastrophes.

\section{Figure 1: Schematic Diagram}

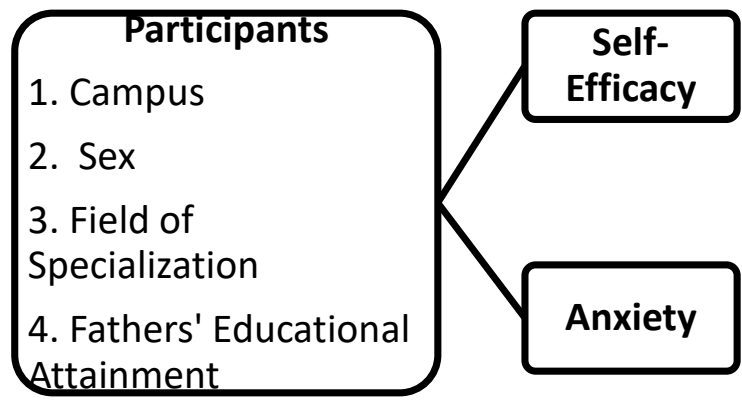

\section{Related Literature and Studies}

In the article of Jacofsky, et. al. (2014) entitled Understanding Anxiety and Anxiety Disorders Introduction, states that anxiety is a very frequent human experience, that describes people provide are quite varied. Anxiety is best considered a complex, subjective experience. Anxiety is produced by multiple causes. It is expressed by a diverse set of symptoms. These symptoms include physical, emotional, behavioral, and cognitive components. Many people vary on common experience; however, get totally different definitions of what it means to be anxious.

Moreover, a normal degree of anxiety is part of the daily human experience. Unfortunately, people may experience anxiety to such a heightened degree that it causes them great distress, this level of anxiety can interfere with people's ability to function well and may affect many significant areas of existence such as work, school, and relationships. It is commonly believed that responses are automatically and unconsciously strengthened by their immediate consequences. Simple performances can be altered to some degree through reinforcement without awareness of the relationship between one's actions and their outcomes (Bandura, 1971; JKU, 2000). However, man's cognitive skills enable him to profit more extensively from experience than if he were an unthinking organism.

In the study of Ochieng, Wenslaus (2014), shows that the male participants have a higher self-efficacy than the female participants, and there was a significant difference on the level of self-efficacy of the participants when grouped according to sex, whereas, in the study of May, Diana (2009), she established that there was no significant difference on the level of self-efficacy of the participants when grouped according to sex. While on the study of Tudy, Randy (2014), there was no significant difference on the level of self-efficacy between genders.

According to Schvaneveldt, Supple, and Bush (2004) cite in the study of Ballo, Ma. Devina (2010) that the higher the level of the paternal educational education the greater feeling of self-efficacy of the child. In the study of Devine, A., Fawcett, K., Szucs, D. and Dowker, A. (2012), reveals that there was no significant difference on the mathematics performance between female and male students, however the female students has a higher level of Mathematics Anxiety than the male students. Same results to the study of Pourmoslemi, A., Nasrolah, E., and Iraj, F. (2013) that the mathematics anxiety of the female students is much higher than the male students and it also shows that there was a significant difference on the mathematics anxiety of the students when grouped according to sex. No different to the study of Ballado, R (2014) so as to the Mathematics Anxiety, female respondents have a higher mathematics anxiety than the male participants.

According to Jordan, et. Al (2006) cited in the study of Geist, Eugene (2010) that the educational attainment may have such a large effect on the mathematical achievement because of the mathematical environment in the home may be less stimulating for families with low educational attainment. Furthermore, parents may have less understanding of mathematical concepts, lower comfort level with mathematics and a negative attitude toward mathematics leading to math anxiety and an aversion to mathematics.

In the study of Fagan, M. et.al (2016), that there was a negatively relationship between the computer selfefficacy and anxiety of the students, but on the study of Barbee P. (2016) there was a positive significant relationship with counselor self-efficacy and student anxiety.

\section{Methodology \\ Research Design}

The study utilized the descriptive-correlation research design, because this method is used to discover relationships among variables and to allow the prediction of future events from present knowledge (Stangor, 2015).

\section{Research Participants}

The participants of the study were the 347 the First Year students of Carlos Hilado Memorial State College, who are officially enrolled last second semester Academic Year 2015 - 2016. Stratified random sampling was used to determine the participants of the study. 


\section{Research Instrument}

The study used the modified Mathematics Self Efficacy and Anxiety Questionnaire (MSEAQ) to measure the level of self - efficacy and anxiety of the students in learning mathematics, the MSEAQ was developed by Dianna May and Shawn Glynn on the year 2008. Since the instrument was modified, a validity and reliability test was established.

Utilizing the Good and Scates Evaluation criteria to test the validity of the instrument, two experts on the field of mathematics and one on the field of psychology examine the instrument. The evaluation criteria established a mean average of 3.96, which was interpreted the validity as very good. However, to test the reliability of the instrument the Cronbach's Alpha was employed. The Cronbach's Alpha established an alpha value 0.807, therefore the instrument was reliable.

\section{Data Gathering Procedure}

The researcher solicited the permission of the President of Carlos Hilado Memorial State College noted by the Dean of School of Arts and Sciences and recommended by the Vice President of Academics. The researcher furnished a letter of request to the Dean's to utilize the first year students as the participants of the study.

The researcher administered the test personally to the participants of the study; the researcher informed the participants of the study that the result of the study was treated as highly confidential.

\section{Data Analysis}

To analyze the quantitative data, the following statistical tools will be used:

For problem 1, to determine the level of self-efficacy and anxiety of the first year college students in learning mathematics, the mean was used.

For problem 2, to determine the level of self-efficacy and anxiety of the first year college students in learning mathematics grouped according to Campus, Sex, Fathers Educational Attainment, and Field of Specialization, mean was used.

For problem 3, to determine the significant difference in level of self-efficacy and anxiety of the first year college in learning mathematics when grouped according to Sex, the independent t-test was used, while the participants are grouped according to Fathers Educational Attainment, and Field of Specialization, the one-way ANOVA was used.

For problem 4, to determine the significant relationship between the level of self-efficacy and anxiety of the first year college students in learning mathematics, the Pearson's-r was used.

\section{Descriptive Results}

The level of self-efficacy $(\mathrm{M}=3.28, \mathrm{SD}=0.683)$ of the participant was high, while the level of anxiety $(\mathrm{M}=3.01, \mathrm{SD}=0.671)$ of the participants was also high.

The Level of Self-efficacy and Anxiety of the First Year College Students in Learning Mathematics

\begin{tabular}{llll}
\hline Level & M & SD & Interpretation \\
\hline Self- & & & \\
efficacy & 3.28 & 0.683 & High Self-efficacy \\
Anxiety & 3.01 & 0.671 & High Anxiety \\
\hline
\end{tabular}

Note: Mean Scale; 1.00-3.00 Low and

$$
\text { 3.01-5.00 High }
$$

The level of self-efficacy of the participants of the following campuses; Talisay ( $\mathrm{M}=3.32, \mathrm{SD}=0.683)$, Alijis $(\mathrm{M}=3.12, \quad \mathrm{SD}=0.690)$, Fortune Towne $(\mathrm{M}=3.30, \mathrm{SD}=0.566)$, and Binalbagan $(\mathrm{M}=3.38$, $\mathrm{SD}=0.650$ ) was high, the student at this degree has somewhat gained self-confidence in functioning intellectually by means of his/her adaptive behavior. Table shows that the mean level of self-efficacy of Binalbagan campus was higher, while the Alijis campus has the lower mean level of self-efficacy, the student at this degree has a little self-reliance on his/her academic comprehension and its utilization.

The Level of Self-efficacy of the First Year College Students in Learning Mathematics when grouped according to campus

\begin{tabular}{llll}
\hline Campus & M & SD & Interp. \\
\hline Talisay $(\mathrm{n}=132)$ & 3.32 & 0.683 & High \\
Alijis $(\mathrm{n}=83)$ & 3.12 & 0.690 & High \\
Fortune Towne $(\mathrm{n}=60)$ & 3.30 & 0.566 & High \\
Binalbagan $(\mathrm{n}=72)$ & 3.38 & 0.650 & High \\
\hline
\end{tabular}

The male participants $(\mathrm{M}=3.37, \mathrm{SD}=0.687)$ mean assessment than the female participants $(\mathrm{M}=3.20$, $\mathrm{SD}=0.687$ ), however the level of self-efficacy of the participants when grouped according to sex was high. These result was also shown to the study of Ochieng, W. (2014) that male students have a higher level of self-efficacy than the female students in learning mathematics.

The Level of Self-efficacy of the First Year College Students in Learning Mathematics when grouped according to Sex

\begin{tabular}{llll}
\hline Sex & M & SD & Interp. \\
\hline Male $(n=169)$ & 3.37 & 0.687 & High \\
Female $(n=178)$ & 3.20 & 0.629 & High \\
\hline
\end{tabular}

The participants taking up Bachelor of Science in Hotel and Restaurant Management $(\mathrm{M}=2.91$, $\mathrm{SD}=0.498$ ) has a low self-efficacy level, whereas the participants on the other field of specialization has a 
high self-efficacy level, where the participants taking up Bachelor of Science in Fisheries $(\mathrm{M}=3.58$, $\mathrm{SD}=0.769$ ) has the highest mean assessment.

The Level of Self-efficacy of the First Year College Students in Learning Mathematics when grouped according to Field of Specialization

\begin{tabular}{llll}
\hline $\begin{array}{l}\text { Field of } \\
\text { Specialization }\end{array}$ & M & SD & Interp. \\
\hline AB $(\mathrm{n}=18)$ & 3.29 & 0.795 & High \\
BSIT $(\mathrm{n}=137)$ & 3.23 & 0.701 & High \\
BSIS $(\mathrm{n}=37)$ & 3.31 & 0.578 & High \\
BSED $(\mathrm{n}=37)$ & 3.28 & 0.651 & High \\
BEED $(\mathrm{n}=21)$ & 3.30 & 0.639 & High \\
BSHRM $(\mathrm{n}=10)$ & 2.91 & 0.498 & Low \\
BSACT $(\mathrm{n}=45)$ & 3.33 & 0.621 & High \\
BSENTRP $(\mathrm{n}=4)$ & 3.47 & 0.267 & High \\
BSFISH $(\mathrm{n}=15)$ & 3.58 & 0.769 & High \\
BSCRIM $(\mathrm{n}=23)$ & 3.33 & 0.599 & High \\
\hline
\end{tabular}

The participants who's fathers educational attainment is an elementary level $(\mathrm{M}=3.39$, $\mathrm{SD}=0.731$ ) has the higher mean assessment, while the participants who's fathers educational attainment is a college graduate $(\mathrm{M}=3.21$, $\mathrm{SD}=0.648$ ) has the lower mean assessment, however the level of self-efficacy of the participants when grouped according to father's educational attainment was high. According to Jordan, et. Al (2006) cited in the study of Geist, Eugene (2010) that the educational attainment may have such a large effect on the mathematical achievement because of the mathematical environment in the home may be less stimulating for families with low educational attainment.

The Level of Self-efficacy of the First Year College Students in Learning Mathematics when grouped according to Father's Educational Attainment

\begin{tabular}{|c|c|c|c|}
\hline $\begin{array}{l}\text { Fathers } \\
\text { Educational } \\
\text { Attainment }\end{array}$ & $\mathbf{M}$ & SD & Interp. \\
\hline $\begin{array}{l}\text { Elementary Level } \\
(\mathrm{n}=54)\end{array}$ & 3.39 & 0.731 & $\begin{array}{l}\text { High Self- } \\
\text { efficacy }\end{array}$ \\
\hline Elementary & & & High Self- \\
\hline Graduate $(n=22)$ & 3.27 & 0.474 & efficacy \\
\hline $\begin{array}{l}\text { High School Level } \\
(n=65)\end{array}$ & 3.31 & 0.700 & $\begin{array}{l}\text { High Self- } \\
\text { efficacy }\end{array}$ \\
\hline $\begin{array}{l}\text { High School } \\
\text { Graduate }(\mathrm{n}=77)\end{array}$ & 3.24 & 0.631 & $\begin{array}{l}\text { High Self- } \\
\text { efficacy }\end{array}$ \\
\hline $\begin{array}{l}\text { College Level } \\
(\mathrm{n}=55)\end{array}$ & 3.26 & 0.602 & $\begin{array}{l}\text { High Self- } \\
\text { efficacy }\end{array}$ \\
\hline $\begin{array}{l}\text { College Graduate } \\
(n=53)\end{array}$ & 3.21 & 0.648 & $\begin{array}{l}\text { High Self- } \\
\text { efficacy }\end{array}$ \\
\hline
\end{tabular}

\section{On Anxiety}

The level of anxiety of Talisay $(\mathrm{M}=3.16, \mathrm{SD}=0.729)$ and Alijis ( $M=3.03, \mathrm{SD}=0.622)$ campus was high, the student at this degree has to some high incidence of anxiety. Whereas the participants in Fortune
Towne $(\mathrm{M}=2.89, \mathrm{SD}=0.554)$ and Binalbagan $(\mathrm{M}=2.89, \mathrm{SD}=0.700)$ campus was low, the student at this degree has a low incidence of anxiety.

The Level of Anxiety of the First Year College Students in Learning Mathematics when grouped according to campus

\begin{tabular}{|c|c|c|c|}
\hline Campus & $\mathbf{M}$ & SD & Interp. \\
\hline Talisay $(n=132)$ & 3.16 & 0.729 & $\begin{array}{l}\text { High } \\
\text { Anxiety } \\
\text { High }\end{array}$ \\
\hline Alijis $(n=83)$ & 3.03 & 0.622 & Anxiety \\
\hline $\begin{array}{l}\text { Fortune Towne } \\
(\mathrm{n}=60)\end{array}$ & 2.95 & 0.554 & $\begin{array}{l}\text { Low } \\
\text { Anxiety }\end{array}$ \\
\hline $\begin{array}{l}\text { Binalbagan } \\
(\mathrm{n}=72)\end{array}$ & 2.89 & 0.700 & $\begin{array}{l}\text { Low } \\
\text { Anxiety }\end{array}$ \\
\hline
\end{tabular}

The level of anxiety of the male participants $(\mathrm{M}=2.95, \mathrm{SD}=0.703)$ was low, while the female participants $(\mathrm{M}=3.05, \mathrm{SD}=0.638)$ was high. Same results to study of Ballado, R (2014), that female respondents have a higher mathematics anxiety than the male participants in learning mathematics.

The Level of Anxiety of the First Year College Students in Learning Mathematics when grouped according to Sex

\begin{tabular}{llll}
\hline Sex & M & SD & Interp. \\
\hline Male $(n=169)$ & 2.95 & 0.703 & Low Anxiety \\
Female $(n=178)$ & 3.05 & 0.638 & High Anxiety \\
\hline
\end{tabular}

The participants taking up $\mathrm{AB}(\mathrm{M}=3.21, \mathrm{SD}=0.514)$, BSIT $(\mathrm{M}=3.05, \quad \mathrm{SD}=0.725), \quad$ BEED $(\mathrm{M}=3.17$, $\mathrm{SD}=0.709), \quad \mathrm{BSHRM} \quad(\mathrm{M}=3.39, \quad \mathrm{SD}=0.442)$, BSENTRP $(\mathrm{M}=3.30, \mathrm{SD}=0.234)$ and BSCRIM $(\mathrm{M}=3.03, \mathrm{SD}=0.683)$ has a high level of anxiety, whereas BSIS $(\mathrm{M}=2.95, \quad \mathrm{SD}=0.610), \quad \mathrm{BSED}$ $(\mathrm{M}=2.78, \mathrm{SD}=0.651)$, BSACT $(\mathrm{M}=2.86, \mathrm{SD}=0.566)$ and BSFISH $(\mathrm{M}=2.76, \mathrm{SD}=0.728)$ has a low level of anxiety.

The Level of Anxiety of the First Year College Students in Learning Mathematics when grouped according to Field of Specialization

\begin{tabular}{llll}
\hline $\begin{array}{l}\text { Field of } \\
\text { Specialization }\end{array}$ & M & SD & Interp. \\
\hline AB $(\mathrm{n}=18)$ & 3.21 & 0.514 & High Anxiety \\
BSIT $(\mathrm{n}=137)$ & 3.05 & 0.725 & High Anxiety \\
BSIS $(\mathrm{n}=37)$ & 2.95 & 0.610 & Low Anxiety \\
BSED $(\mathrm{n}=37)$ & 2.78 & 0.651 & Low Anxiety \\
BEED $(\mathrm{n}=21)$ & 3.17 & 0.709 & High Anxiety \\
BSHRM $(\mathrm{n}=10)$ & 3.39 & 0.442 & High Anxiety \\
BSACT $(\mathrm{n}=45)$ & 2.86 & 0.566 & Low Anxiety \\
BSENTRP $(\mathrm{n}=4)$ & 3.30 & 0.234 & High Anxiety \\
BSFISH $(\mathrm{n}=15)$ & 2.76 & 0.728 & Low Anxiety \\
BSCRIM $(\mathrm{n}=23)$ & 3.03 & 0.683 & High Anxiety \\
\hline
\end{tabular}


The level of anxiety of participants who's fathers educational attainment are elementary graduate $(\mathrm{M}=3.15, \mathrm{SD}=0.666)$, high school level $(\mathrm{M}=3.03$, $\mathrm{SD}=0.731)$, and high school graduate $(\mathrm{M}=3.21$, $\mathrm{SD}=0.588$ ) was high, while the level of anxiety of participants who's fathers educational attainment are elementary level $(\mathrm{M}=2.75, \mathrm{SD}=0.626)$, college level $(\mathrm{M}=2.96, \mathrm{SD}=0.590)$ and college graduate $(\mathrm{M}=2.90, \mathrm{SD}=0.722)$ was low. According Geist, Eugene (2010), the parents with less understanding of mathematical concepts lowers' the comfort level with mathematics may lead to math anxiety of the students in learning mathematics.

The Level of Anxiety of the First Year College Students in Learning Mathematics when grouped according to Father's Educational Attainment

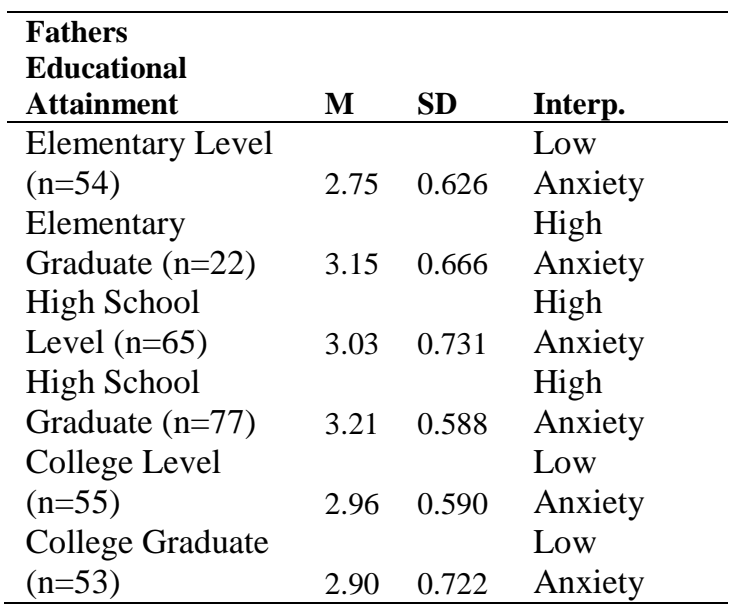

\section{Inferential Results \\ On Self-efficacy}

There was a significant difference in the level of self-efficacy of the first year college students in learning mathematics when grouped according to $\operatorname{sex}[\mathrm{t}(345)=2.464, \mathrm{p}=0.014]$. The same results with study of Ochieng, W. (2014), there was a significant difference on the level of self-efficacy of the participants when grouped according to sex, but contradicts to the study of May, D. (2009), she established that there was no significant difference on the level of self-efficacy of the participants when grouped according to sex.

Difference in Level of Self-efficacy of the First Year College Students in Learning Mathematics when grouped according to Sex

\begin{tabular}{lccccc}
\hline \multirow{2}{*}{$\begin{array}{l}\text { Self- } \\
\text { efficacy }\end{array}$} & Male & Female & df & $\mathbf{t}$ & $\mathbf{p}$ \\
\cline { 2 - 6 } & $(0.687)$ & $(0.629)$ & 345 & $\begin{array}{c}2.464 \\
* *\end{array}$ & 0.014 \\
\hline Note: $* *$ & $\mathrm{p}<0.05$
\end{tabular}

There was no significant difference in the level of self-efficacy of the first year college students in learning mathematics when grouped according to campus $[\mathrm{F}(3,343)=2.194, \mathrm{p}=0.089]$.

Difference in Level of Self-efficacy of the First Year College Students in Learning Mathematics when grouped according to Campus

\begin{tabular}{lcccc}
\hline Campus & $\mathbf{M}$ & $\mathbf{d f}$ & $\mathbf{F}$ & $\mathbf{p}$ \\
\hline Talisay & & & & \\
$(\mathrm{n}=132)$ & 3.32 & & & \\
& $(0.683)$ & & & \\
Alijis $(\mathrm{n}=83)$ & 3.12 & & & \\
& $(0.690)$ & & & \\
Fortune & & 3,343 & 2.194 & 0.089 \\
Towne (n=60) & 3.30 & & & \\
& $(0.566)$ & & & \\
Binalbagan & & & & \\
$(\mathrm{n}=72)$ & 3.38 & & & \\
& $(0.650)$ & & & \\
\hline
\end{tabular}

There was no significant difference in the level of self-efficacy of the first year college students in learning mathematics when grouped according to field of specialization $[\mathrm{F}(9,337)=0.852, \mathrm{p}=0.569]$.

Difference in Level of Self-efficacy of the First Year College Students in Learning Mathematics when grouped according to Field Specialization

\begin{tabular}{|c|c|c|c|c|}
\hline $\begin{array}{l}\text { Field of } \\
\text { Specialization }\end{array}$ & $\mathbf{M}$ & df & $\mathbf{F}$ & $\mathbf{p}$ \\
\hline $\mathrm{AB}(\mathrm{n}=18)$ & $\begin{array}{c}3.29 \\
(0.795)\end{array}$ & & & \\
\hline BSIT $(n=137)$ & $\begin{array}{c}3.23 \\
(0.701)\end{array}$ & & & \\
\hline BSIS (n=37) & $\begin{array}{c}3.31 \\
(0.578)\end{array}$ & & & \\
\hline BSED (n=37) & $\begin{array}{c}3.28 \\
(0.651)\end{array}$ & & & \\
\hline $\operatorname{BEED}(n=21)$ & $\begin{array}{c}3.30 \\
(0.639)\end{array}$ & & & \\
\hline $\begin{array}{l}\text { BSHRM } \\
(n=10)\end{array}$ & $\begin{array}{c}2.91 \\
(0.498)\end{array}$ & 9,337 & 0.852 & 0.569 \\
\hline $\begin{array}{l}\text { BSACT } \\
(n=45)\end{array}$ & $\begin{array}{c}3.33 \\
(0.621)\end{array}$ & & & \\
\hline $\begin{array}{l}\text { BSENTRP } \\
(\mathrm{n}=4)\end{array}$ & $\begin{array}{c}3.47 \\
(0.267)\end{array}$ & & & \\
\hline $\begin{array}{l}\text { BSFISH } \\
(n=15)\end{array}$ & $\begin{array}{c}3.58 \\
(0.769)\end{array}$ & & & \\
\hline $\begin{array}{l}\text { BSCRIM } \\
(n=23)\end{array}$ & $\begin{array}{c}3.33 \\
(0.599)\end{array}$ & & & \\
\hline
\end{tabular}

There was no significant difference in the level of self-efficacy of the first year college students in learning mathematics when grouped according to 
father's educational attainment $[\mathrm{F}(5,320)=0.5$, $\mathrm{p}=0.776]$.

Significant Difference in Level of Self-efficacy of the First Year College Students in Learning Mathematics when grouped according to Father's Educational Attainment

\begin{tabular}{|c|c|c|c|c|}
\hline $\begin{array}{l}\text { Fathers } \\
\text { Educational } \\
\text { Attainment }\end{array}$ & $\mathbf{M}$ & df & $\mathbf{F}$ & p \\
\hline $\begin{array}{l}\text { Elementary } \\
\text { Level }(n=54)\end{array}$ & $\begin{array}{c}3.39 \\
(0.731)\end{array}$ & & & \\
\hline $\begin{array}{l}\text { Elementary } \\
\text { Graduate } \\
(\mathrm{n}=22)\end{array}$ & $\begin{array}{c}3.27 \\
(0.474)\end{array}$ & & & \\
\hline $\begin{array}{l}\text { High School } \\
\text { Level }(n=65)\end{array}$ & $\begin{array}{c}3.31 \\
(0.700)\end{array}$ & & & \\
\hline $\begin{array}{l}\text { High School } \\
\text { Graduate } \\
(n=77)\end{array}$ & $\begin{array}{c}3.24 \\
(0.631)\end{array}$ & 5,320 & 0.5 & 0.776 \\
\hline $\begin{array}{l}\text { College } \\
\text { Level }(n=55)\end{array}$ & $\begin{array}{c}3.26 \\
(0.602)\end{array}$ & & & \\
\hline $\begin{array}{l}\text { College } \\
\text { Graduate } \\
(n=53)\end{array}$ & $\begin{array}{c}3.21 \\
(0.648) \\
\end{array}$ & & & \\
\hline
\end{tabular}

There was no significant difference in the level of anxiety of the first year college students in learning mathematics when grouped according to sex $[\mathrm{t}(345)=-1.284, \mathrm{p}=0.2]$, same results with the study of Devine, A. et.al (2012), reveals that there was no significant difference on the mathematics performance between female and male students, however the female students has a higher level of Mathematics Anxiety than the male students.

Difference in Level of Anxiety of the First Year College Students in Learning Mathematics when grouped according to Sex

\begin{tabular}{cccccc}
\hline \multirow{3}{*}{ Anxiety } & Male & Female & df & t & p \\
\cline { 2 - 6 } & $\begin{array}{c}2.95 \\
(0.703)\end{array}$ & $\begin{array}{c}3.05 \\
(0.638)\end{array}$ & 345 & -1.284 & 0.2 \\
\hline
\end{tabular}

There was no significant difference on the level of anxiety of the first year college students when grouped according to campus $[\mathrm{F}(3,343)=1.105$, 0.347]

Difference in Level of Anxiety of the First Year College Students in Learning Mathematics when grouped according to Campus

\begin{tabular}{|c|c|c|c|c|}
\hline Campus & $\mathbf{M}$ & df & $\mathbf{F}$ & $\mathbf{p}$ \\
\hline $\begin{array}{l}\text { Talisay } \\
(n=132)\end{array}$ & $\begin{array}{c}3.16 \\
(0.729)\end{array}$ & & & \\
\hline Alijis $(n=83)$ & $\begin{array}{c}3.03 \\
(0.622)\end{array}$ & & & \\
\hline $\begin{array}{l}\text { Fortune Towne } \\
(\mathrm{n}=60)\end{array}$ & $\begin{array}{c}2.95 \\
(0.554)\end{array}$ & 3,343 & 1.105 & 0.347 \\
\hline $\begin{array}{l}\text { Binalbagan } \\
(\mathrm{n}=72)\end{array}$ & $\begin{array}{c}2.89 \\
(0.700)\end{array}$ & & & \\
\hline
\end{tabular}

There was no significant difference on the level of anxiety of the first year college students when grouped according to field specialization $[\mathrm{F}(9$, 337) $=1.848, \mathrm{SD}=0.059$ ].

Difference in Level of Anxiety of the First Year College Students in Learning Mathematics when grouped according to Field of Specialization.

\begin{tabular}{|c|c|c|c|c|}
\hline Field of Specialization & M & df & $\mathbf{F}$ & $\mathbf{p}$ \\
\hline $\mathrm{AB}(\mathrm{n}=18)$ & $\begin{array}{c}3.21 \\
(0.514)\end{array}$ & \multirow{10}{*}{9,337} & \multirow{10}{*}{1.848} & \multirow{10}{*}{0.059} \\
\hline BSIT (n=137) & $\begin{array}{l}3.05 \\
(0.725)\end{array}$ & & & \\
\hline BSIS (n=37) & $\begin{array}{c}2.95 \\
(0.610)\end{array}$ & & & \\
\hline $\operatorname{BSED}(n=37)$ & $\begin{array}{c}2.78 \\
(0.651)\end{array}$ & & & \\
\hline $\operatorname{BEED}(n=21)$ & $\begin{array}{l}3.17 \\
(0709)\end{array}$ & & & \\
\hline BSHRM $(n=10)$ & $\begin{array}{c}3.39 \\
(0.442)\end{array}$ & & & \\
\hline $\operatorname{BSACT}(n=45)$ & $\begin{array}{c}2.86 \\
(0.566)\end{array}$ & & & \\
\hline $\operatorname{BSENTRP}(n=4)$ & $\begin{array}{c}3.30 \\
(0.234)\end{array}$ & & & \\
\hline BSFISH $(n=15)$ & $\begin{array}{c}2.76 \\
(0.728)\end{array}$ & & & \\
\hline BSCRIM (n=23) & $\begin{array}{c}3.03 \\
(0.683)\end{array}$ & & & \\
\hline
\end{tabular}

There was a significant difference in the level of anxiety of the first college students in learning mathematics when grouped according to father's educational attainment $[\mathrm{F}(5, \quad 320)=3.785$, $\mathrm{SD}=0.002]$. Utilizing the Scheffe method, the mean of high school graduates creates difference with the elementary level with a mean difference of 0.46330 .

Difference in Level of Anxiety of the First Year College Students in Learning Mathematics when grouped according to Father's Educational Attainment 


\begin{tabular}{lcccc}
\hline $\begin{array}{l}\text { Fathers } \\
\text { Educational } \\
\text { Attainment }\end{array}$ & $\mathbf{M}$ & $\mathbf{d f}$ & $\mathbf{F}$ & $\mathbf{p}$ \\
\hline $\begin{array}{l}\text { Elementary } \\
\text { Level (n=54) }\end{array}$ & $\begin{array}{c}2.75 \\
(0.626)\end{array}$ & & & \\
$\begin{array}{l}\text { Elementary } \\
\text { Graduate } \\
(\mathrm{n}=22)\end{array}$ & 3.15 & & & \\
& $(0.666)$ & 5,320 & 3.785 & 0.002 \\
$\begin{array}{l}\text { High School } \\
\text { Level (n=65) }\end{array}$ & 3.03 & & & \\
$\begin{array}{l}\text { High School } \\
\text { Graduate } \\
(\mathrm{n}=77)\end{array}$ & & & & \\
\hline
\end{tabular}

\begin{tabular}{lc}
\hline $\begin{array}{l}\text { College Level } \\
(\mathrm{n}=55)\end{array}$ & $(0.588)$ \\
& 2.96 \\
College & $(0.590)$ \\
$\begin{array}{l}\text { Graduate } \\
(\mathrm{n}=53)\end{array}$ & 2.90 \\
& $(0.722)$ \\
\hline
\end{tabular}

Note: $* * \mathrm{p}<0.05$

Based from the post hoc analysis utilizing the Scheffe Method, the participants whose fathers are high school graduates creates difference with the participants whose fathers are elementary level with mean difference of 0.46330 .

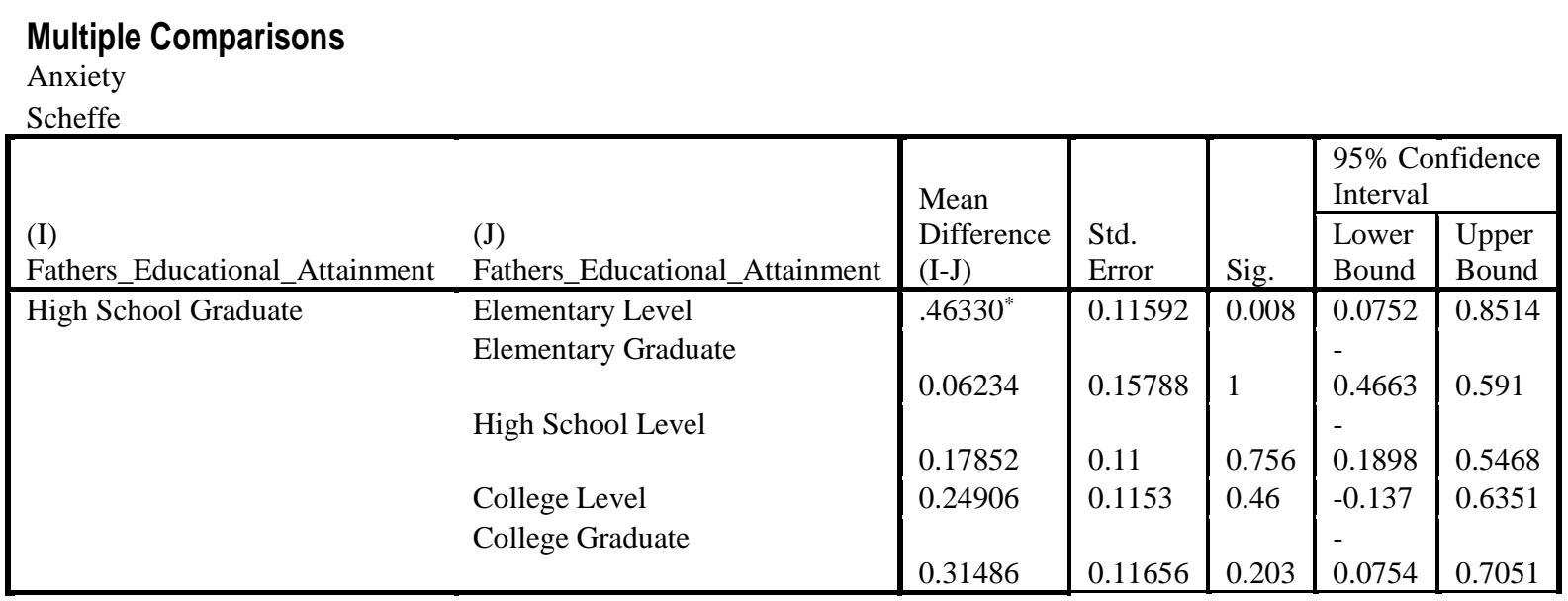

*The mean difference is significant at the 0.05 level.

There was a weak negative relationship between the level of self-efficacy and anxiety of the first year college students in learning mathematics $[\mathrm{r}(347)=$ $0.333, p=0.00]$. The results of the study contradict to the study of Barbee (2016), there was a positive relationship between self-efficacy and anxiety.

Relationship between the Level of Self-efficacy and Anxiety of the First Year College Students in Learning Mathematics

\begin{tabular}{llll}
\hline Relationship & N & r & p \\
Self-Efficacy * Anxiety & 347 & $-0.333 * *$ & 0.00 \\
\hline
\end{tabular}

Note: $* * \mathrm{p}<0.05$,

\section{Conclusion and Recommendation Conclusion}

The level of self-efficacy of the college students in learning mathematics was high. However, when the participants are grouped according to field of specialization, the participants taking up BSHRM has a low level of self-efficacy. Moreover, results show that the self-efficacy of the male students in learning mathematics was higher than the female students.
The level of anxiety of the students in learning mathematics was also high. The female participants and the student taking up AB, BSIT, BEED, BSHRM, BSENTRP, and BSCRIM, and student whose fathers are Elementary Graduate, High School Level and High School Graduates illustrates high level of anxiety in learning mathematics.

Lastly, the level of self-efficacy of the students exhibit a weak negative relationship with the level of anxiety of the students, this signify that the higher the self-efficacy of the students shows in learning mathematics the lower the level of anxiety of the student's experience, or vice versa.

\section{Recommendation}

The Carlos Hilado Memorial State College Administrators must provide further consideration through conducting seminar-workshops on engendering mathematics manuals and adapting teaching strategies to cater the needs of the students, to develop the capabilities of the students towards mathematics, especially to the campuses and field of specialization with low level of self-efficacy and high level of anxiety. 
The Mathematics Department must provide awareness and consideration through developing strategies and generate instructional models to enhance the self-efficacy and lowers the level of anxiety of the students in learning mathematics.

The Mathematics Teacher must attend training to enhance teaching skills and strategies to cater the needs of the students; he/she should create an environment that the students are free to ask questions and inquiries towards the subject in order increase the self-efficacy and lowers the anxiety of the students in learning mathematics.

The Students must learn how to address their needs to their mathematics teachers and be more accountable to their self on learning mathematics.

The Future Researcher should perform research on the factors that affects the self-efficacy and anxiety of the students in learning mathematics.

\section{Conflict of Interest}

There is no Conflict of Interest in this work.

\section{References}

1. American Psychology Association (APA), (2015). Anxiety, http://www.apa.org/topics/ anxiety/, Retrieved September 15, 2015, Tuesday.

2. American Psychology Association (APA), (2015). Self-efficacy, http://www.apa.org/pi/ aids/resources/education/self-efficacy.aspx, Retrieved September 15, 2015, Tuesday.

3. Agarwal, Nidhi, (2018). "A Study of Innovations in Instructional Strategies and Designs for Quality Enrichment in Higher Education" Cosmos: An International Journal of Art \& Higher Education, 7(2), ISSN: 23198966.

4. Agarwal, Nidhi and Kumar, Puneet, (2009). "Reflection on the New Innovations for Maximizing the Learning in Teacher of Mathematics". International Journal Educational Herald, 38(2); 41, ISSN: 09740732. Available at SSRN: https://ssrn.com/abstract=3600864, http://doi.org/10.5281/zenodo.3826567.

5. Ballado, Renato, (2014). Mathematics Anxiety and Academic Achievement of Junior Preservice Teacher Education Students, University of Eastern Philippines, International Academic Conference Proceedings 2014, www.westeastinstitute.com, Date

Retrieved: July 11, 2016, Monday.

6. Ballo, Ma. Divina, (2010). Self-efficacy in English: A comparison of first year and fourth year students' language self-efficacy in the Philippines and the factors affecting self- efficacy, Universitetet I Oslo, www.duo.uio.no, Date Retrieved: July 11, 2016, Monday.

7. Barbee, P., (2016). Prepracticum servicelearning: examining the relationship with counselor self-efficacy and anxiety.

8. Beyers, J.E.R., (2008). Development and evaluation of an instrument to measure prospective teachers' dispositions with respect to mathematics (Doctoral dissertation). Retrieved from ProQuest (Order No. 3329788).

9. Cates, G.L. and Rhymer, K.N., (2003). Examining the relationship between mathematics Anxiety and mathematics performance: An instructional hierarchy perspective. Journal of Behavioral Education, $12 ; 23-34$.

10. Damon, W., (2007). Dispositions and teacher assessment the need for a more rigorous definition.Journal of Teacher Education, 58(5), 365-369, Retrieved September 13, 2015, Sunday.

11. Fagan, M., et.al., (2016). An Empirical Investigation into the Relationship between Computer Self-Efficacy, Experience, Support and Usage, Journal of Computer Information Systems, 44(2), www.tandfonline.com, Date Retrieved: July 14, 2016, Thursday.

12. Devine, A., Fawcett, K., Szucs, D. and Dowker, A., (2012). Gender differences in Mathematics Anxiety and Relation to Mathematics Performance while controlling for test Anxiety, www.ncbi.nlm.nih.gov, Date Published: July 9, 2012, Date retrieved: July 11, 2016, Monday.

13. Goel, Ankit and Agarwal, Ekansh, (2019). Assessing Innovation in Teacher Education. Globus Journal of Progressive Education, 9(2); 50-52, ISSN: 2231-1335.

14. Hannula, M., (2006). Motivation in mathematics: Goals reflected in emotions. Educational Studies in Mathematics, 63; 165178.

15. Higbee, J.L., \& Thomas, P.V., (1999). Affective and cognitive factors related to Mathematics achievement. Journal of Developmental Education, 23; 8-24.

16. Jacofsky, M., et. al., (2014). Understanding Anxiety and Anxiety Disorders Introduction, http://www.gracepointwellness.org/1-anxietydisorders/article/38463-understanding-anxietyand-anxiety-disorders-introduction, Retrieved September 13, 2015, Sunday.

17. JKU, (2000), Social Learning Theory, http://www.jku.at/org/content/e54521/e54528/ e54529/e178059/Bandura_SocialLearningTheo ry_ ger.pdf, Retrieved September 13, 2015, Sunday.

18. Kalder, R.S. and Lesik, S.A., (2011). A classification of attitudes and beliefs towards mathematics for secondary mathematics preservice teachers and elementary pre-service 
teachers: An exploratory study using latent class analysis. Issues in the Undergraduate Mathematics Preparation of School Teachers, 5.

19. Kazelskis, R., et.al., (2000). Mathematics anxiety and test anxiety: Separate constructs? Journal of Experimental Education, 68; 137146.

20. May, Diana, (2009). Mathematics Self-efficacy and Anxiety Questionnaire, University of Georgia, www.getd.libs.uga.edu, Date Retrieved: July 11, 2016, Monday.

21. May, D., \& Glynn, S., (2008). A Mathematics Self-Efficacy Questionnaire for college students. Paper presented at the annual meeting of Research in Undergraduate Mathematics Education, San Diego.

22. Middleton, J.A. and Spanias, P.A., (1999). Motivation for achievement in mathematics: Findings, generalizations, and criticisms of the research. Journal for Research in Mathematics Education, 30; 65-88.

23. Ochieng, Wenslaus, (2015). Self-efficacy and Academic Achievement among Secondary Schools in Kenya: Mathematics Perspective, University of Nairobi, www.erepository.uonbi.ac.ke, Date Retrieved: July 11, 2016, Monday.

24. Pajares, F., (2006). Overview of Social Cognitive Theory and of Self-Efficacy, http://edutechwiki.unige.ch/en/Self-

efficacy_theory, Retrieved September 13, 2015, Sunday.

25. Pajares, F (2002). Overview of social cognitive theory and of selfefficacyhttp://www.emory.edu/EDUCATION/ mfp/eff.html, Retrieved September 13, 2015, Sunday.

26. Peer, K. and McClendon, R., (2002), Sociocultural Learning Theory in Practice: Implications for Athletic Training Educators, http://edutechwiki.unige.ch/en/Self-

efficacy_theory, RetrievedSeptember 13, 2015, Sunday.

27. Phillips, M., (2015), The Causes and Prevention of Math Anxiety, Math Goodies, www.mathgoodies.com, Date Retrieved: July 13, 2016, Wednesday.

28. Psychology Glossary, (2015), Attitude, http://www.alleydog.com/glossary/definition.p hp?term=Attitudes, Retrieved September 15, 2015, Tuesday.

29. Ramírez, M.J., (2003). The distribution of mathematics knowledge among Chilean fourth graders and related explanatory factors. EducarChile.com.

30. Stangor, C., (2015). Psychologists Use Descriptive, Correlational, and Experimental Research Designs to Understand Behavior, Flat World Education, Inc., http://catalog.flatworldknowledge.com/bookhu b/127? e=stangor-ch02_s02, Retrieved September 15, 2015, Tuesday.

31. Staples, S., (1998). Four Major Sources of Information of Self-efficacy, Journal of Computer-Mediated Communication, http://edutechwiki.unige.ch/en/Self-

efficacy_theory, Retrieved September 13, 2015, Sunday.

32. Pourmoslemi, Alireza, Nasrolah, Erfani and Iraj, Firoozfar, (2013). Mathematics Anxiety, Mathematics Performance and Gender differences among Undergraduate Students. International Journal of Scientific and Research Publications, 3(7), July 2013. www.ijsrp.org, Date Retrieved: July 11, 2016, Monday.

33. Tapia, M., \& Marsh, G.E., (2004). An instrument to measure mathematics attitudes. Academic Exchange Quarterly, 8(2); 16-21.

34. Taylor, Stevens, (2010). Anxiety Sensitivity, Lawrence Erlbaum Associates, Page 13.

35. Tiwari, Rashmi, (2018). Effect of Women Empowerment in India with The Consideration of Economic Development. Globus An International Journal of Management \& IT, 9(2), ISSN: 0975-721X.

36. Tudy, Randy, (2014), Attitude, Self-efficacy and Students' Academic Performance, Philippine E-Journal, www.ejournals.ph, 12(1), Date Retrieved: July 11, 2016, Monday.

How to cite this article:

Bearneza, Francis Jose D., (2020). The Self-Efficacy and Anxiety in Learning Mathematics of College Students. Globus Journal of Progressive Education, 10(1): 101-110. 